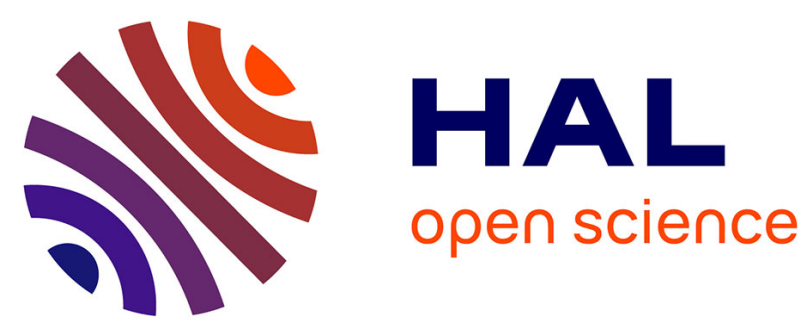

\title{
Effectiveness of a mitigation technique for buildings subjected to ground subsidence
}

\author{
Boramy Hor, Matthieu Caudron, Marwan Al Heib, Fabrice Emeriault
}

\section{To cite this version:}

Boramy Hor, Matthieu Caudron, Marwan Al Heib, Fabrice Emeriault. Effectiveness of a mitigation technique for buildings subjected to ground subsidence. International conference on advances in geotechnical engineering (ICAGE 2011), Nov 2011, Perth, Australia. pp.651-656. ineris-00973638

\section{HAL Id: ineris-00973638}

\section{https://hal-ineris.archives-ouvertes.fr/ineris-00973638}

Submitted on 4 Apr 2014

HAL is a multi-disciplinary open access archive for the deposit and dissemination of scientific research documents, whether they are published or not. The documents may come from teaching and research institutions in France or abroad, or from public or private research centers.
L'archive ouverte pluridisciplinaire HAL, est destinée au dépôt et à la diffusion de documents scientifiques de niveau recherche, publiés ou non, émanant des établissements d'enseignement et de recherche français ou étrangers, des laboratoires publics ou privés. 


\title{
Effectiveness of a Mitigation Technique for Buildings subjected to Ground Subsidence
}

\author{
Boramy Hor ${ }^{1}$, Matthieu Caudron ${ }^{2}$, Marwan Al Heib ${ }^{2}$ and Fabrice Emeriault ${ }^{3}$ \\ ${ }^{1} \mathrm{PhD}$ student in Civil Engineering, University of Lyon, INSA-Lyon, France \\ ${ }^{2}$ Researchers, INERIS, France \\ ${ }^{3}$ Professor of Geotechnical Engineering, Grenoble-INP, France
}

\begin{abstract}
Synopsis: A physical modelling has been undertaken to study the effectiveness of a mitigation technique (peripheral trench) to protect a residential house undergoing a ground surface subsidence from mining. A simple building model and a foam-material trench model are designed and implemented. Their deformations are measured by Digital Image Correlation (DIC) technique. The 3D physical model was proved very potential to qualitatively study the impact of ground movements on surface structures and the effect of soil-structure interaction. The trench technique was pointed out very effective to protect the building. The strain in the building and its surrounding ground are significantly reduced by the presence of the trench dug around the building.
\end{abstract}

Keywords: physical modelling, ground movements, soil-structure interaction, mitigation technique.

\section{Introduction}

Subsidence of the ground surface can be regarded as ground movement which takes place due to the extraction of mineral resources and the collapse of underground structure. The subsidence parameters and the behaviour of the overlying structures located in different positions are presented in Figure $1 \mathrm{a}$. Unfortunately, subsidence may have serious effects on surface structures and services. Prior to construction, the ground movements should be predicted and their consequences on the structures and services should be assessed. If the assessment of structure damage shows a not negligible level of risk, the protection measures have to be taken into consideration.

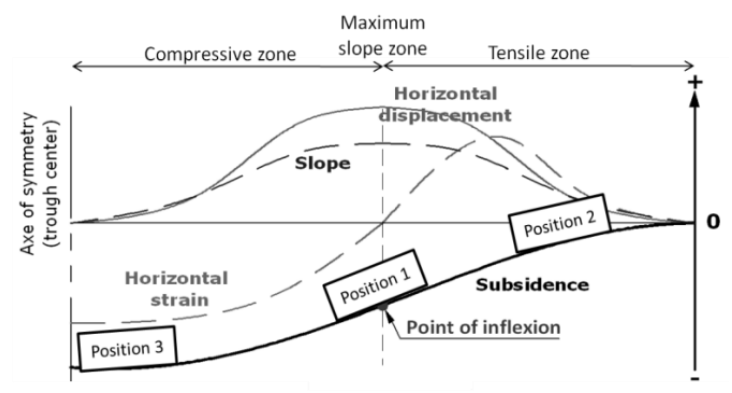

(a)

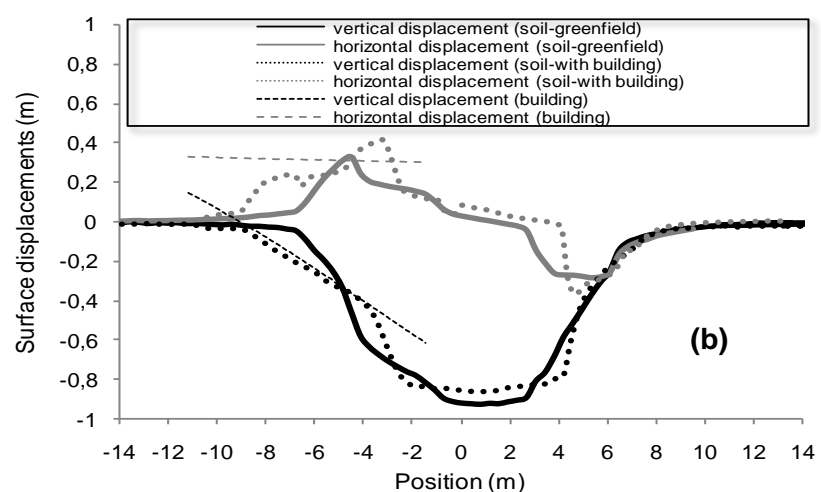

Figure 1. (a) Subsidence parameters and structure's behaviour for different positions at ground level; (b) Example of results from physical modelling

Depending on the severity and causes of estimated damage, one or more mitigation techniques have to be designed and implemented to reduce the vulnerability or to eliminate potential structure damage. Peng et al. [1] have used many mitigation techniques to protect the 12 residential houses that were undermined by longwall mining in the US coalfields. Those techniques are peripheral trench, plan-fitting method, tension cable, and external bracing. They were proved very effective, inexpensive, and easy to implement.

The main objective is to evaluate the effectiveness of the peripheral trench technique to prevent subsidence-induced damage to a residential house by means of physical modelling developed by INERIS.

This paper first summarises the different existing tools used to study the characteristics of a protection measure by peripheral trench. Then, we will briefly describe the 3D physical model, the building model, and the trench model. Much of the content is drawn from the discussion on the effectiveness of the protection measure using data from experimental tests. 


\section{Mitigation Technique - Peripheral Trench}

A trench creates a weak zone in the ground which absorbs ground strain rather than transferring it from soil to structure. It is very effective when dealing with compressive ground strain and is universally acceptable to home owner because it does not involve the house structure [1].

The peripheral trench technique to protect the buildings from subsidence-induced damage due to mining has been widely studied and applied to engineering practices. Many researchers have conducted different approaches to study the effectiveness of the trench. Whittaker et Reddish [2] and Peng et al. [1] used the field observation method to study the effectiveness of the trench. Peng et al. [1] showed a reduction of $60 \%$ by comparing the maximum compressive strain measured across the trench and that measured across the house. The trench used in the field observation tests was filled with loose material (loose hay) and had the dimensions of about $0.6 \mathrm{~m}$ wide, $0.6 \mathrm{~m}$ below the basement floor, and $1.2 \mathrm{~m}$ away from the basement block wall.

Numerical modelling was also carried out [3, 4]. Al Heib [3] developed a series of 2D numerical analyses to investigate the influence of a peripheral trench on the soil and structure behaviours. The modelled structure is a masonry wall subjected only to the imposed horizontal ground strains of $0.6 \%$ and $1.2 \%$. The trench was empty and its dimensions are $0.5 \mathrm{~m}$ wide, $1 \mathrm{~m}$ deep from the ground level, and the trench was placed at $1 \mathrm{~m}$ from the foundation. The results pointed out that the trench technique may reduce the strain in the ground below the building from $30 \%$ to $40 \%$.

The field observation method is budget and time consuming, whereas the numerical analyses adopt important hypotheses that somewhat make it more difficult to understand and to explain the physical phenomenon. Physical modelling approach has an advantage, since it provides a direct and clear message to get the physical understanding. This paper reports the experimental results of the effectiveness of peripheral trench by means of physical modelling.

\section{Physical Modelling}

\subsection{The Apparatus}

The details of the hypotheses, conception, and limitations, as well as the monitoring method of the smallscale physical model can be found in [5].

The model is designed to be used in $1 \mathrm{~g}$ environment (earth gravity). It is therefore difficult for quantitative interpretations to the experimental data to be made. One objective of the model is to simulate the surface ground movements due to mining. To represent the typical mining cases which have the soil volume up to $150 \times 100 \times 50 \mathrm{~m}^{3}$, the small-scale model has to be able to hold a soil block of $3 \times 2 \times 1 \mathrm{~m}^{3}$ with a maximum geometric scale of $1 / 50$. The main hypothesis of the model is the abstraction of the cavity collapse, thus only the study of the phenomena at surface level is focused. The movements at ground surface are achieved by vertically moving an "electric jack" placed at the bottom of the model downwards. The results of the surface displacements of the grounds in greenfield and with building as well as the building displacements can be seen in Figure 1b.

In this paper, we consider a mining case of $20 \mathrm{~m}$ depth with $10 \times 10 \mathrm{~m} 2$ area of extraction. In the model scale, this is equivalent to an overburden of $0.5 \mathrm{~m}$ and a jack section of $0.25 \times 0.25 \mathrm{~m} 2$ for a geometric scale of $1 / 40$. The chosen geometric scale makes it possible to use the Fontainebleau sand which is very fine to model the soil. The diameter of the grains varies from 0.1 to $0.3 \mathrm{~mm}$ with D50 approximately 0.2 $\mathrm{mm}$. The estimated properties of the soil mass model are presented in the Table 1.

Table 1. Properties of different materials of the models used in physical simulations.

\begin{tabular}{|c|c|c|c|}
\hline Parameter & $\begin{array}{c}\text { Soil } \\
\text { (Fontainebleau sand) }\end{array}$ & $\begin{array}{c}\text { Building } \\
\text { (Polycarbonate) }\end{array}$ & $\begin{array}{c}\text { Trench } \\
\text { (Melamine Foam) }\end{array}$ \\
\hline Unit weight $\left(\mathrm{kN} / \mathrm{m}^{3}\right)$ & 16 & 12 & $0.08-0.11$ \\
\hline Modulus of elasticity $(\mathrm{MPa})$ & $5-20$ & $2200-2500$ & $0.01-0.02$ \\
\hline Cohesion $\left(\mathrm{kN} / \mathrm{m}^{2}\right)$ & $0-2$ & - & - \\
\hline Friction angle (degrees) & $32-36$ & - & - \\
\hline
\end{tabular}




\subsection{The Building Model}

A building model was created to investigate the impact of ground movements on the surface structure. The chosen geometry for the building was inspired from the existing database of buildings damaged by mining subsidence in the east of France. A typical two-floor house of $10 \mathrm{~m} \times 10 \mathrm{~m}$ constituted by masonry walls, reinforced concrete slabs, and superficial foundations was considered. This realistic but complex 3D prototype scale model was simplified for defining the small-scale model. The procedure of simplification can be found in $[5,6]$.

The structure model is indeed a U-section slab (see Figure 2) made of polycarbonate, the interior part of which is composed of lead powder in plastic bags. This allows the model to present a stiffness and a stress transmitted to the ground approximately equivalent to those of the prototype. The $5 \mathrm{~mm}$ width of the edge is designed to be visible to the camera for measurement during the test.

\subsection{The Measurement Technique}

Digital Image Correlation (DIC) was adopted to determine the deformations of the ground and the building model. Two high-resolution digital cameras whose relative position is very precisely known allow determining the 3D deformations of the specimen's surfaces using a correlation software Vic3D (Figure 2). In addition, this method provides an accurate result with a small error on the Fontainebleau sand (about $0.03 \mathrm{~mm}$ for a whole test)

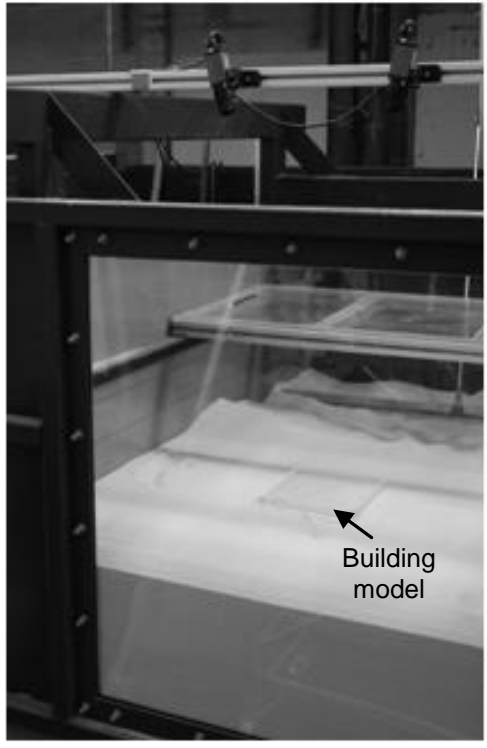

(a)

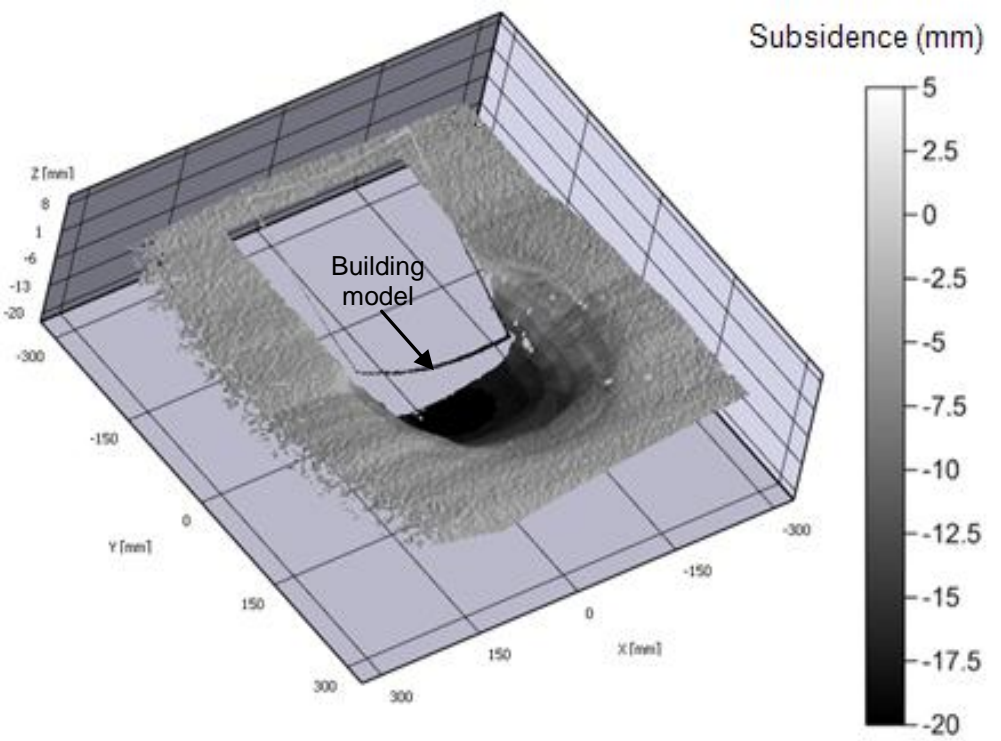

(b)

Figure 2. Monitoring of the physical model: (a) Two digital cameras capturing the surface of soil and building model; (b) Example of the 3D shape of the soil and building model determined by Vic3D using DIC technique (only the edges of the structure can be analysed)

\subsection{The Trench Model}

The material filling the trench has to be less stiff than that of the soil foundation. This allows the trench absorbing well the ground strains (see Figure 3a). Melamine foam was chosen for its ability to deform in compression, its physical aspect, and its ease of implementation. The Table 1 shows the great difference between the elasticity modulus of the melamine trench model and that of the Fontainebleau soil model. The melamine foam is about 500 to 2000 times softer than the Fontainebleau sand. The peripheral trench is composed of many blocks lining around the building model (see Figure 3b). At prototype scale, the 
section of the trench is $60 \mathrm{~cm}$ wide and $120 \mathrm{~cm}$ deep below the foundation (ground level) and it is placed at $1.4 \mathrm{~m}$ and $0.4 \mathrm{~m}$ from the building.

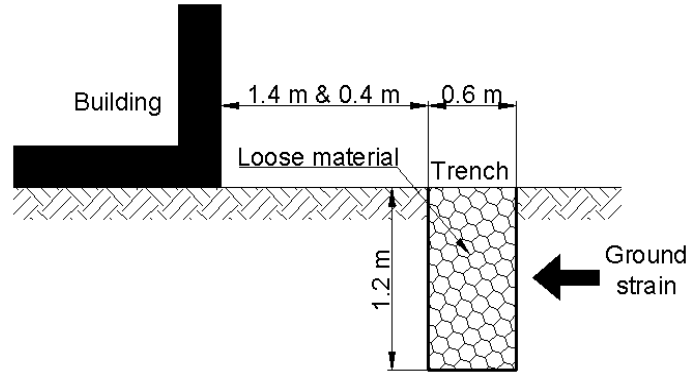

(a)

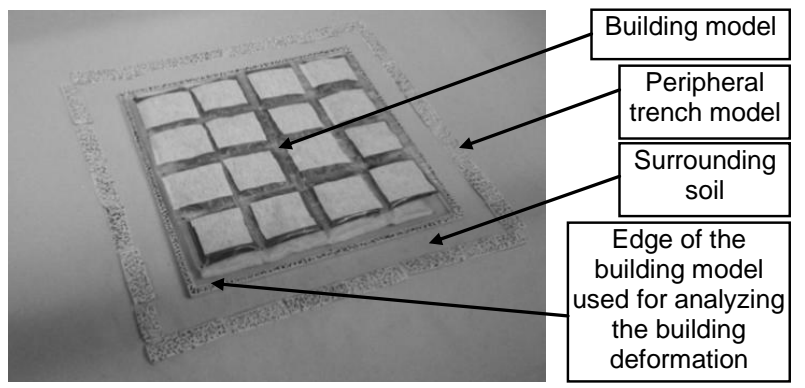

(b)

Figure 3. (a) Presentation of peripheral trench technique; (b) Building model lying on the ground and peripheral trench model

\section{Experimental Results}

The physical model makes it possible to study the soil-structure interaction. The discussion on the results can be found in $[5,6]$.

To investigate the effectiveness of the trench, the tests were undertaken in three configurations (see Figure 4). For each configuration, two identical tests were carried out to ensure a good repeatability of the results. The variation of the results from one test to another is not remarkable, but cannot be neglected.
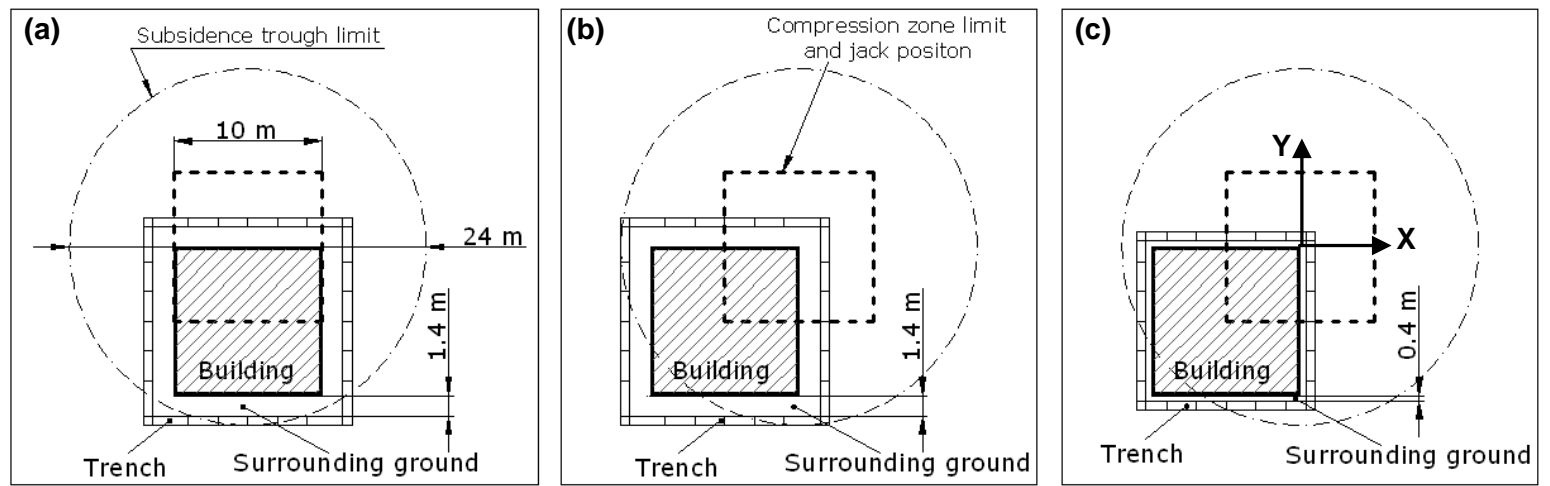

Figure 4. Different configurations of the tests: (a) Trench placed at $1.4 \mathrm{~m}$ from the building located in maximum slope zone; (b) Trench placed at $1.4 \mathrm{~m}$ from the building located in tensile zone; (c) Trench placed at $0.4 \mathrm{~m}$ from the building located in tensile zone

Two important parameters were taken into account: the influences of the building's position and the distance between the trench and the building. The building model was positioned in maximum slope zone and in tensile zone. Two distances of $1.4 \mathrm{~m}$ and $0.4 \mathrm{~m}$ between the trench and the building located in tensile zone were tested, whereas only a distance of $1.4 \mathrm{~m}$ was assigned for the building in maximum slope zone. The chosen distances are based on the real practices.

The physical model makes it possible to estimate the effectiveness of the peripheral trench by either comparing the horizontal strain in the building or the strain of the ground surrounding it under conditions with and without the presence of the trench.

As mentioned above, the trench protects more effectively the buildings undergoing compressive strain. However, only some parts of the building and peripheral trench are subjected to the compressive strain. The physical model at the present state limits to provide very generalized subsidence trough, which 
makes it impossible to place the whole building and the trench in the compressive zone. Figure $4 \mathrm{~b}$ shows that the compression zone is limited within about the jack area. The strains of the building and its surrounding ground are then determined within the compressive area. The strain of building at maximum slope is observed on the only edge in compressive zone along $\mathrm{X}$-axis, whereas the edge along the $\mathrm{Y}$-axis is considered to determine the strain of building at tensile zone. The surrounding ground strains of any case are analysed following the $\mathrm{Y}$-axis.

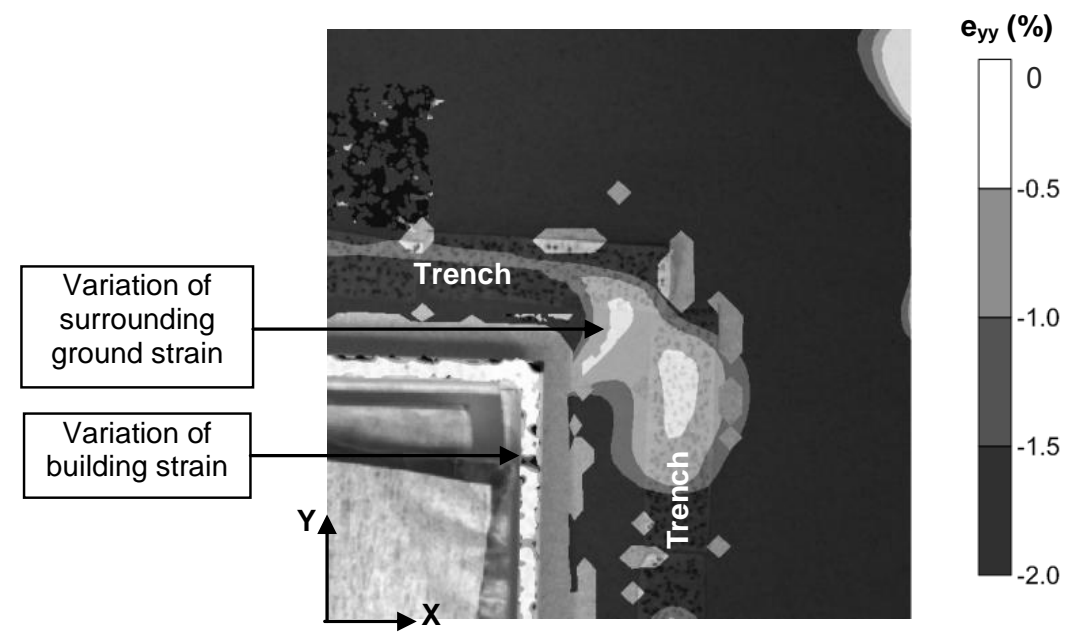

Figure 5. Contour values of horizontal strains for building at tensile zone with trench placed at a distance of $1.4 \mathrm{~m}$

The strains obtained from the DIC technique greatly vary from one point to another, as shown in Figure 5. It is very difficult to interpret such a result. The determination of the building and the ground strain is then done in a macroscopic manner. The building strain is calculated by differentiating the measured horizontal displacements on either side of the building divided by the distance between the two sides. The horizontal ground strain is measured within the area between the building and the trench. The values of the ground strain are obtained by averaging the strains given from DIC technique within the compressive zone. Table 2 shows the horizontal strains of the ground around the building and the building itself (negative value denotes compression) under conditions with and without the trench. For each configuration, the results are obtained from only one test. In configuration where the trench placed very close to the building at 0.4 $\mathrm{m}$, the surrounding ground data is unable to be analysed by the DIC technique. It is also important to note that all the results are measured at the surface of the models and some points of the interest area failed to be analysed (see Figure 5).

In any case, the amount of strain of the building is remarkably smaller than that of the ground. Reasons could be that the building is just laid on the ground (no foundation system), the axial stiffness of the building is relatively important, and the building model is designed to perform in the elastic domain $[5,6]$.

Table 2. Average horizontal strains of building and its surrounding ground

\begin{tabular}{|c|c|c|c|c|c|c|c|}
\hline \multirow{2}{*}{$\begin{array}{c}\text { Building's } \\
\text { position }\end{array}$} & \multirow{2}{*}{$\begin{array}{c}\text { Distance } \\
\text { between } \\
\text { trench \& } \\
\text { building }(\mathrm{m})\end{array}$} & \multicolumn{2}{|l|}{ Horizontal ground strain (\%) } & Horizontal building strain (\%) & \multicolumn{2}{l|}{ Strain reduction (\%) } \\
\cline { 3 - 8 } & 1.4 & -2.88 & -0.93 & -0.20 & -0.13 & -67.7 & -35.0 \\
\hline $\begin{array}{c}\text { At maximum } \\
\text { slope zone }\end{array}$ & 1.4 & -2.26 & -1.79 & -0.16 & -0.07 & -20.8 & -56.3 \\
\hline $\begin{array}{c}\text { At tensile } \\
\text { zone }\end{array}$ & 0.4 & - & - & -0.16 & -0.10 & - & -37.5 \\
\hline
\end{tabular}


For structure located in maximum slope zone, the average compressive strains in Table 2 shows a reduction of almost $70 \%$ on the horizontal strain of the ground surrounding the building in the case with the presence of the trench comparing to the case without the trench. On the other hand, the reduction is $35 \%$ regarding to the building strain.

For structure in tensile zone, the trench diminishes about $21 \%$ of the surrounding ground strain. Around $56 \%$ and $38 \%$ of strain reduction are found in the buildings with the trench at $1.4 \mathrm{~m}$ distance and at $0.4 \mathrm{~m}$ distance respectively.

From the obtained results, we can provide the following judgements:

- The effectiveness of the trench depends on the position of the building. In terms of the ground strain, the trench is much more effective for the maximum slope position; while it is less effective, regarding to the building strain.

- The closer the distance between the building and the trench, the less effective is the peripheral trench.

The efficiency of the trench analysed by physical modelling is very similar to the results from observations in real cases [1] and those from numerical modellings [3] (see section 2). This clearly shows the effectiveness of the trench.

\section{Conclusion and Further Work}

The physical modelling approach was carried out to study the behaviour of a mitigation technique - i.e. peripheral trench used to protect the building damage due to ground movements. The trench described in this paper has proved very effective in reducing the compressive strain in the ground and also in the building. Its effectiveness varies depending on the building location relatively to the subsidence trough, and on the distance from the building. The trench closer to the building is less effective than that placed far away.

The obtained results are interesting since they are comparable with those from observations and numerical modellings. However, many hypotheses imposed in the physical modelling should be improved for future works for a better reflection to the real practices:

- The building should be improved to more closely represent a real building with a foundation system and the upper part of the structure.

- The surface ground subsidence should be developed for a more generalized one which makes it possible to place the whole building and peripheral trench in the compressive zone.

- Only the deformations at the surface level can be measured so far, the measurement technique should be then ameliorated to access to the deformations at underground level.

\section{References}

1. Peng, S.S., Luo, Y. and Dutta, D., "An Engineering Approach to Ground Surface Subsidence Damage Due to Long-wall Mining", Mining Technology, 78(900), 1996, pp. 227-231.

2. Whittaker, B.N. and Reddish, D.J., "Subsidences: Occurrence, Prediction and Control", Elsevier Science, 1989, New York.

3. Al Heib, M., "Influence de la déformation horizontale sur le bâti - Rôle d'une tranchée périphérique", Journées nationales de géotechnique et de géologie de l'ingénieur, LCPC-Nantes, 2008, pp. 159-166.

4. Luo, Y., Peng, S.S., and Dutta, D., "Some mitigative measures for protection of surface structures affected by ground subsidence", Proceeding of the 3rd workshop on Surface subsidence due to underground mining, West Virginia University, 1992, pp 129-138

5. Caudron, M., Hor, B., Emeriault, F. and Al Heib, M., "A large 3D physical model: a tool to investigate the consequences of ground movements on the surface structure", 14th Int. Conf. on Experimental Mechanics, EDP sciences, Poitiers, France, 2010, pp 22001(1-8).

6. Hor, B., Emeriault, F., Caudron, M. and Al Heib, M., "Analyse expérimentale de l'impact de mouvements de terrain sur le bâti de surface", Journées nationales de géotechnique et de géologie de l'ingénieur, Grenoble-INP, 2010, tome 1, pp 263-270. 